\title{
Neuropsychomotor development in children and adolescents with liver diseases: systematic review with meta-analysis
}

\author{
Juliana Costa SANTOS ${ }^{1,2}$, Micheli Bernardone SAQUETT0 ${ }^{1}$, Mansueto GOMES NET0 ${ }^{1}$, \\ Josiane de Lima dos SANTOS ${ }^{1}$ and Luciana Rodrigues SILVA ${ }^{1}$
}

Received: 8 September 2020

Accepted: 7 December 2020

\begin{abstract}
Background - The nature of liver disease, the evolutionary course and duration of liver diseases, as well as the degree of severity and disability can trigger multiple outcomes with repercussions on neuromotor acquisition and development. Objective - To systematically review and conduct a meta-analysis to evaluate the effects of liver disease on the neuropsychomotor development of children and adolescents with their native livers and those who underwent liver transplantation. Methods - Observational studies published since the early 1980s until June 2019 were sought in the PubMed and Scopus databases. An $\alpha$ value of 0.05 was considered significant. The statistical heterogeneity of the treatment effect between the studies was assessed by the Cochran's Q test and the I 2 inconsistency test, in which values above 25 and $50 \%$ were considered indicative of moderate and high heterogeneity, respectively. Analyses were performed with Review Manager 5.3. Results - Twenty-five studies met the eligibility criteria, including 909 children and adolescents with liver disease. Meta-analyses showed deficits in total IQ -0.41 (95\%CI: -0.51 to -0.32; N: 9,973), verbal IQ $-0.38(95 \% \mathrm{CI}$ : -0.57 to $-0.18 ; \mathrm{N}: 10,284)$ and receptive language $-0.85(95 \% \mathrm{CI}:-1.16$ to $-0.53 ; \mathrm{N}$ : 921$)$ in liver transplantation, and those with native livers who had symptoms early had total and verbal IQ scores $(85 \pm 8.8 ; 86.3 \pm 10.6$ respectively) lower than the scores of those with late manifestations (99.5 \pm 13.8 ; 96.2 \pm 9.2 ). Gross motor skill was reduced -46.29 (95\%CI: -81.55 to -11.03 ; N: 3,746). Conclusion - Acute or chronic liver disease can cause declines in cognitive, motor and language functions. Although the scores improve after liver transplantation, children remain below average when compared to healthy children.
\end{abstract}

Keywords - Liver disease; liver transplantation; child development.

\section{INTRODUCTION}

Childhood liver diseases may be diagnosed at a late moment or even be underdiagnosed by pediatricians due to their asymptomatic character or nonspecific signs and symptoms in the initial phase ${ }^{(1)}$, acute manifestation or progression to chronicity, with onset or persistence of changes in biochemical and/or laboratory test ${ }^{(1,2)}$. In Brazil, there are about 61.2 million children ${ }^{(2)}$, and the number of children needing liver transplantation (LT) to survive grows every year. In recent years, an average of 204 liver transplants have been performed per year, with a survival rate greater than $90 \%$ in the first year after this procedure ${ }^{(3)}$.

With the increase in life expectancy after treatment of liver diseases, it is observed that the focus of professionals who deal with these children has expanded from mere survival to a careful look at long-term functionality and quality of life ${ }^{(4)}$. Neuropsychomotor aspects, such as cognitive function, and motor and social development are essential skills for the adequate school development and future occupational activity of these children and adolescents and also for family balance ${ }^{(5)}$
Some studies have shown cognitive deficits in attention, intelligence, motor and language deficits in patients with liver diseases ${ }^{(5-8)}$. The earlier the brain is exposed to neurotoxic disease conditions, the greater the neuropsychomotor damage. On the other hand, the shorter the time between indication and transplantation, the less damage to the immature neurological system and the greater the chances of recovery due to neuroplasticity in young patients ${ }^{(5)}$. However, little is known about the motor development of children who remain with their native liver ${ }^{(6)}$.

In 2018, Rodijk et al. ${ }^{(6)}$ carried out a systematic review with the objective of determining neurodevelopmental results in children with liver disease, but without meta-analysis. To our knowledge, no meta-analysis compiling data on neuropsychomotor development involving children and adolescents with acute and chronic liver diseases has been published so far. Thus, the aim of this study was to systematically review the effects of liver disease on the neuropsychomotor development of children and adolescents with their native livers and of those who underwent LT, and compare the results of cognitive, language and motor skills between these two groups through a meta-analysis. 


\section{METHODS}

Systematic review and meta-analysis carried out according to PRISMA recommendations and guidelines.

\section{Selection criteria}

Nineteen cross-sectional and six longitudinal studies that investigated aspects of neuropsychomotor (neurocognitive and neuromotor) development of children and adolescents with acute and chronic liver diseases were included in the study. The results of interest were: intelligence coefficients (full and verbal IQ), perceptual reasoning, working memory, processing speed, general, receptive and expressive language, general motor skill, manual dexterity, ability with a ball and balance. Articles in which the age of the participants was $\geq 18$ years and which presented other diseases in addition to liver diseases were excluded.

\section{Search strategy}

Searches were performed in the databases PubMed and Scopus databases, including the first studies published in the 1980s until June 2019, without restrictions of language or publication status. The search was carried out by two independent reviewers, who read the titles and abstracts. A third reviewer read the articles in full length and applied the inclusion and exclusion criteria for selection of manuscripts. The references of the included articles were revised to identify potential studies. The following Medical Subject Headings (MeSH) and Health Sciences Descriptors (DeCS) in the English language were used as keywords: "liver diseases in children", "developmental disorders", "neuropsychomotor delays", "cognitive delays", "child liver transplantation", "learning disorders", "motor delays", "chronic liver failure" and "observational studies", with combinations made using "AND" and/or "OR".

\section{Assessment of methodological quality}

The Newcastle-Ottawa scale (NOS) for quality assessment was used to evaluate the risks of bias in the included studies ${ }^{(7)}$. Ten stars were adopted for cross-sectional studies. A maximum of six stars was assigned to cohort studies, since none of the included studies selected an unexposed cohort and no comparison could be made. Adequate follow-up was defined as that conducted for at least 12 months.

\section{Statistical analysis}

Estimates of the combined effect were obtained by comparing the minimum squares of the average percentage variation between measures obtained for each group, and were expressed as weighted average differences between groups. The calculations were made using a random effects model. Two comparisons were made: Post-liver transplant group versus control group and Pre-liver transplant group versus control group. Reference values for standardization of the scales that evaluated the variables in each study were used to perform the meta-analysis of studies that did not have a control group ${ }^{(9-12)}$.

An $\alpha$ value of 0.05 was considered significant. The statistical heterogeneity of the treatment effect between studies was assessed by the Cochran Q test and the inconsistency index test, where values above 25 and $50 \%$ were considered to indicate moderate and high heterogeneity, respectively. If meta-analysis was not possible due to clinical heterogeneity, data were analyzed descriptively. All analyses were performed using Review Manager version 5.0 (Cochrane Collaboration) ${ }^{(13)}$

\section{RESULTS}

\section{Description of selected studies}

Initially, 8,124 related articles were identified. After reading the titles and abstracts, the two independent reviewers selected 72 articles, which were considered potentially relevant. A third reviewer read the studies in full length and applied the inclusion and exclusion criteria, and a total of 25 articles were selected (FIGURE 1). The number of participants with liver diseases was 909, and 649 underwent LT. The period of publication of the studies was from 1988 to 2018; the size of the population with liver diseases studied in the articles varied between $13^{(14)}$ to $144^{(9)}$, and the average age of the participants ranged from $3^{(10)}$ months to 18 years ${ }^{(11)}$. Results of the assessment of risk of bias are presented in FIGURE 2.

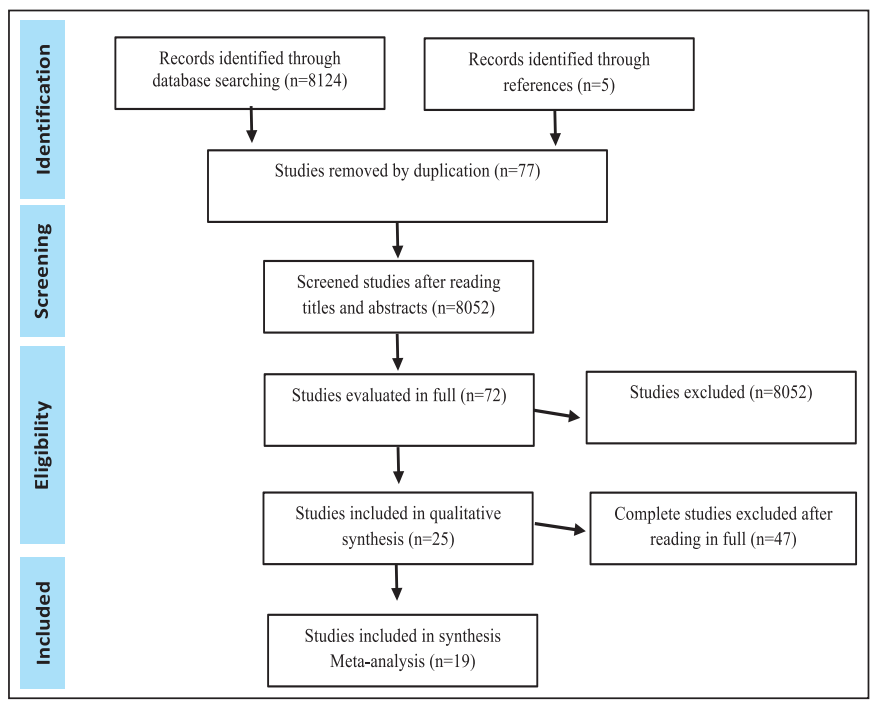

FIGURE 1. Flow diagram of studies for inclusion in the systematic review.

\begin{tabular}{|c|c|c|c|c|}
\hline Cross-sectional & Selection & Comparability & Outcome & $\begin{array}{l}\text { Study } \\
\text { quality }\end{array}$ \\
\hline Lee et al., 2017 & $* \star * *$ & * & $* * *$ & $7 / 10$ \\
\hline Kaller et al., 2013 & $* * * *$ & ** & $\star * * *$ & $9 / 10$ \\
\hline Sorensen et al., 2015 & $* * * *$ & ** & $\star \star * *$ & $9 / 10$ \\
\hline Sorensen et al., 2011 & $* * * *$ & * & *** & $8 / 10$ \\
\hline Sorensen et al., 2014 & $\star \star \star \star *$ & ** & *** & $9 / 10$ \\
\hline Afshar et al., 2018 & $* * * *$ & ** & $\star * *$ & $9 / 10$ \\
\hline Macedo et al., 2017 & $* * \star *$ & ** & *** & $9 / 10$ \\
\hline Almaas et al., 2015 & $\star * * * *$ & ** & $\star \star * *$ & $9 / 10$ \\
\hline Ee et al., 2014 & $\star * * * *$ & ** & *** & $10 / 10$ \\
\hline Haavisto et al., 2011 & $\star \star \star \star *$ & ** & $\star \star * *$ & $9 / 10$ \\
\hline Caudle et al., 2012 & $* * * *$ & ** & *** & $9 / 10$ \\
\hline Caudle et al., 2010 & $* * * *$ & ** & *** & $9 / 10$ \\
\hline Abu Faddan et al., 2014 & $* * *$ & * & *** & $7 / 10$ \\
\hline Krull et al., 2003 & 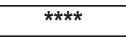 & * & $\star * *$ & $8 / 10$ \\
\hline Rodrigue et al., 2009 & $\star \star * \star *$ & * & $* * *$ & $8 / 10$ \\
\hline Gold et al., 2017 & $* * * *$ & * & *** & $8 / 10$ \\
\hline Stewart et al., 1991 & $* * *$ & ${ }^{*}$ & $* * *$ & $7 / 10$ \\
\hline Kaller et al., 2010 & $* * *$ & ** & $* * *$ & $8 / 10$ \\
\hline Stewart et al., 1988 & $\star * *$ & ** & $\star * *$ & $8 / 10$ \\
\hline Cohort & Selection & Comparability & Outcome & Total \\
\hline Sorensen et al., 2018 & ** & $=$ & $\star * *$ & $5 / 6$ \\
\hline Gilmour et al., 2009 & ** & $=$ & $* * *$ & $5 / 6$ \\
\hline NG et al., 2018 & ** & $=$ & $\star \star * *$ & $5 / 6$ \\
\hline Wayman et al., 1997 & ** & $=$ & ** & $4 / 6$ \\
\hline van Mourik et al., 2000 & ** & $=$ & ** & $4 / 6$ \\
\hline Stewart et al., 1989 & ** & $=$ & $* * *$ & $5 / 6$ \\
\hline
\end{tabular}

FIGURE 2. Quality assessment of included studies. 


\section{Study characteristics}

All studies investigated some aspect of neuropsychomotor development in children and adolescents with acute and/or chronic liver diseases. Nineteen studies were conducted with children after LT. The most common diseases were biliary atresia, cholestatic diseases, and diseases of metabolic and viral etiologies. Eight studies had a control group. Nineteen studies were subject to meta-analysis.

Ten instruments were used to evaluate the variables of interest. For cognition and executive functions, versions of the Wechsler
Intelligence Scales (WISC) were the most used $(15 / 17)^{(5,9,12,14-22)}$. General, fine and gross motor development were assessed using the following instruments: Movement Assessment Battery for Children (M-ABC) ${ }^{(23)}$, Mullen Scales of Early Learning (MSEL) ${ }^{(10,24)}$, Bayley Development Scales ${ }^{(25,26)}$, Griffiths Mental Ability Scales (GMDS) ${ }^{(27)}$ and General Development Scale of Minnesota Child Development Inventory (MCDI) ${ }^{(15)}$. Some of these instruments also evaluated general language ${ }^{(25)}$, receptive and expressive language ${ }^{(10,24)}$ (TABLE 1).

TABLE 1. Characterization of studies on neuropsychomotor development in children and adolescents with liver disease.

\begin{tabular}{|c|c|c|c|c|c|}
\hline Authors / year & Study design & $\begin{array}{l}\text { Participants / age } \\
\text { range }\end{array}$ & Liver disease & Assessment & Neurognitive results \\
\hline Lee et al., 2017 & Cross-sectional & $28(0.5-15.3$ years $)$ & Chronic (LT)/BA & WPPSI-III & $=$ FSIQ, VIQ \\
\hline Kaller et al., 2013 & Cross-sectional & 64/64 (6-16 years) & $\begin{array}{c}\text { Chronic (LT) /BA, CD } \\
\text { MGD }\end{array}$ & WISC-IV & $\downarrow$ FSIQ, VIQ, PRI, WMI, PSI \\
\hline Sorensen et al., 2015 & Cross-sectional & $36 /(6-16$ years $)$ & $\begin{array}{l}\text { Acute (LT)/ AT, AD, MD, } \\
\text { VI, IN, OT }\end{array}$ & WISC-IV & = FSIQ, VIQ, PRI, WMI, PSI \\
\hline Sorensen et al., 2018 & Longitudinal & $25 /(<18$ years $)$ & $\begin{array}{c}\text { Acute (LT)/AT, AD, MD, } \\
\text { VI, IN, OT }\end{array}$ & WISC-IV & = FSIQ, VIQ, PRI, WMI, PSI \\
\hline Sorensen et al., 2011 & Cross-sectional & $144 /(5-7$ years $)$ & $\begin{array}{l}\text { Acute and Chronic (LT)/BA, } \\
\text { CD, MD, AHI, OT }\end{array}$ & WPPSI-III & $\downarrow \mathrm{FSIQ}, \mathrm{VQI}, \mathrm{PRI},=\mathrm{PSI}$ \\
\hline Sorensen et al., 2014 & Cross-sectional & 93 (7-9 years) & $\begin{array}{l}\text { Acute and chronic (LT)/ BA, } \\
\text { CD, MD, AHI, OT }\end{array}$ & WISC-IV & $\downarrow \mathrm{FSIQ}, \mathrm{VQI}=\mathrm{PRI}, \downarrow \mathrm{WMI}, \mathrm{PSI}$ \\
\hline Afshar et al., 2018 & Cross-sectional & 40 (6-16 years) & $\begin{array}{c}\text { Chronic (LT) /BA, AD, } \\
\text { A1AT, OT }\end{array}$ & WISC-IV & $\downarrow$ FSIQ, VIQ, PRI, WMI, = PSI \\
\hline Macedo et al., 2017 & Cross-sectional & 45/60 (2-7 years) & $\begin{array}{l}\text { Chronic (LT)/ BA, } \\
\text { CD, CR, A1AT, OT }\end{array}$ & TELD -3 & $\begin{array}{l}\downarrow \text { Receptive language } \\
=\text { expressive language }\end{array}$ \\
\hline Almaas et al., 2015 & Cross-sectional & $35 / 480$ (4-12 years) & $\begin{array}{c}\text { Chronic (LT) /BA, CD, } \\
\text { A1AT, OT }\end{array}$ & $\mathrm{M}-\mathrm{ABC}$ & $\begin{array}{l}\downarrow \text { General motor skills, manual } \\
\text { dexterity, ball skills, balance }\end{array}$ \\
\hline Ee et al., 2014 & Cross-sectional & $13 / 6$ (6-17 years) & $\begin{array}{c}\text { Chronic (LT) /BA, CD, } \\
\text { A1AT, OT }\end{array}$ & WISC-IV & = FSIQ, VIQ, WMI, PSI \\
\hline Haavisto et al., 2011 & Cross-sectional & 18/17 (7-16 years) & $\begin{array}{c}\text { Acute and chronic (LT) /BA, } \\
\text { AHI, OT }\end{array}$ & WISC-IIII & $=$ FSIQ, VIQ \\
\hline Caudle et al., 2012 & Cross-sectional & 33 (3-20 months) & Chronic (before LT) /BA & MSEL & $\begin{array}{l}\downarrow \text { Receptive and expressive language, } \\
\text { ball skills, = manual dexterity }\end{array}$ \\
\hline Caudle et al., 2010 & Cross-sectional & 15 (4-21 months) & Chronic (before LT) /BA & MSEL & $\begin{array}{c}\downarrow \text { Receptive and expressive language, } \\
\text { ball skills, manual dexterity }\end{array}$ \\
\hline Abu Faddan et al., 2014 & Cross-sectional & $35 / 23$ (3-18 years) & Chronic (before LT) /HTC & Stanford-Binettest & $\downarrow$ FSIQ \\
\hline Gilmour et al., 2009 & Logitudinal & 20 (>47 months) & Chronic (LT) /BA, OT & WISC-IIII & $\downarrow$ FSIQ, VIQ \\
\hline Krull et al., 2003 & Cross-sectional & 15 (4-12 years) & $\begin{array}{c}\text { Chronic (LT) /BA, } \\
\text { A1AT, DC }\end{array}$ & $\begin{array}{l}\text { WPPSI-R/WISC- } \\
\text { III/CELF-P/CELFR }\end{array}$ & $\begin{array}{l}\downarrow \text { FSIQ, VIQ, receptive, expressive } \\
\text { and general language }\end{array}$ \\
\hline Rodrigue et al., 2009 & Cross-sectional & 114 (9-11 years) & Chronic (pre - LT) /HTC & BRIEF $\mathrm{T}$ & $\uparrow \mathrm{WMI}$ \\
\hline $\mathrm{Ng}$ et al., 2018 & Longitudinal & 42 (<42 months) & Chronic (pre - LT) /BB & Bayley III & $\begin{array}{c}\downarrow \text { General language, gross motor } \\
\text { skills }\end{array}$ \\
\hline Wayman et al., 1997 & $\begin{array}{l}\text { Longitudinal } \\
\text { (1year LT) }\end{array}$ & 40 ( $<2$ years $)$ & Chronic (LT) /BB & Bayley & $\downarrow$ FSIQ, general motor skills \\
\hline Van Mourik et al., 2000 & $\begin{array}{l}\text { Longitudinal } \\
\text { (1 year LT) }\end{array}$ & $\begin{array}{c}14(<12 \text { months }-5 \\
\text { years })\end{array}$ & $\begin{array}{c}\text { Acute and chronic (LT) /BA, } \\
\text { A1AT, OT }\end{array}$ & GMAS & $\begin{array}{c}\downarrow \text { General language, } \uparrow \text { general } \\
\text { motor skills, ball skills, } \downarrow \text { manual } \\
\text { dexterity }\end{array}$ \\
\hline Stewart et al., 1989 & $\begin{array}{l}\text { Longitudinal } \\
\text { (1 year LT) }\end{array}$ & $\begin{array}{c}14 \text { (3 months-16 } \\
\text { years) }\end{array}$ & $\begin{array}{c}\text { Chronic (LT) /BA, A1AT, } \\
\text { OT }\end{array}$ & WISC, MCDI & $\downarrow$ FSIQ, VIQ, general motor skills \\
\hline Gold et al., 2017 & Cross-sectional & $13 / 5$ (3-7 years) & Chronic (LT) /BA, A1A, OT & WPPSI-IV & $=\mathrm{FSIQ}$ \\
\hline Stewart et al., 1991 & Cross-sectional & 28 (4-14 years) & $\begin{array}{c}\text { Chronic (LT) /BA, A1AT, } \\
\text { OT }\end{array}$ & WISC-R & $=\mathrm{VIQ}$ \\
\hline Kaller et al., 2010 & Cross-sectional & 59 (6-18 years) & Chronic (LT) /BA & TAP & $\downarrow$ WMI \\
\hline Stewart et al., $1988^{* *}$ & Cross-sectional & $21 / 15(0-12$ years $)$ & Chronic (pre LT) BA, A1AT & WISC & $\downarrow$ FSIQ, VIQ \\
\hline
\end{tabular}

*Average scores/no significant difference with norms / control groups. $\uparrow$ High scores/significantly higher than norms / control groups. $\downarrow$ Low scores/significantly lower than norms / control groups. LT: live transplantation; WPPSI/ WISC: Wechsler intelligence scales; FSIQ: full scale intelligence quotient; VIQ: verbal intelligence quotient; PRI: perceptual reasoning index; WMI: working memory index; PSI: processing speed index. BA: biliary atresia; CD: cholestatic diseases; MGD: metabolic genetic diseases; AT: acetaminophen toxicity; AD: autoimmune diseases; MD: Metabolic disorders; VI: viral infections; CR: cirrhosis; A1AT: alpha-1-antitrypsin deficiency; HTC: hepatitis C; ALF: acute liver failure; AHI: acute hepatic infections; IN: indeterminate; OT: others; CELFP / CELFR: clinical evaluation of language fundamentals; GMAS: griffiths mental ability scales; MCDI: Minnesota child development Inventory); TAP: test of attentional performance. **Results of children with early clinical manifestations under the age of 12 months. 


\section{NEUROPSYCHOMOTOR RESULTS} AFTER LIVER TRANSPLANTATION

\section{Full scale intelligence quotient - FSIQ}

Fourteen studies evaluated the full total intelligence coefficient with WISC ${ }^{(5,9,12,14-19,26,28-31)}$. Eleven studies had no control group and the meta-analysis was made using the reference values of the instrument $\mathrm{t}^{(5,9,12,15,17-19,28-30)}$. It was demonstrated that transplanted children aged 20 months to 18 years had a lower full IQ - 0.41 (95\%CI: -0.51 to $-0.32 ; \mathrm{N}: 9,973$ ) compared to the group with reference values. The meta-analysis of the studies which had a control group ${ }^{(14,16,31)}$ also showed a worse full IQ in transplanted recipients $-0.53(95 \% \mathrm{CI}$ : -0.85 to $-0.22 ; \mathrm{N}: 165)$. All studies revealed a reduction in total IQ -0.42 (95\%CI: -0.51 to -0.33 ; N: 10,138) (FIGURE 3.A).

\section{Verbal intelligence quotient - VIQ}

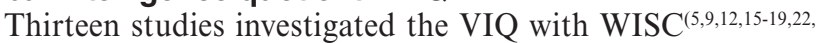
28-29,32). The meta-analysis of studies compared with reference values showed that transplanted children and adolescents had worse verbal IQ -0.38 (95\%CI: -0.57 to $-0.18 ; \mathrm{N}: 10,284)$. The same was seen in two studies conducted with control groups $-0.47(95 \% \mathrm{CI}$ : -0.80 to $-0.14: \mathrm{N}: 147)^{(16,32)}$. The worst verbal IQ was maintained when the meta-analysis was made with all studies $-0.39(95 \% \mathrm{CI}$ : -0.56 to -0.22 : N: 10,431) (FIGURE 3.B).

\section{Perceptual reasoning - PRI}

Six studies investigated this variable with WISC ${ }^{(9,12,17-19,31)}$. Only one study had a control group, making it impossible to perform a meta-analysis between groups. The meta-analysis showed a decline in the Perceptual Reasoning Index in transplanted children aged 5 to 16 years, in relation to the reference values $-0.30(95 \% \mathrm{CI}$ : -0.41 to -0.19 ; N: 5,483) (FIGURE 3.C).

\section{Working memory - WMI}

Seven studies evaluated working memory with WISC in the population aged 6 to 18 years ${ }^{(12,16-19,31,32)}$. The meta-analysis of the studies compared with reference values $(5 / 7)^{(12,17-19,32)}$ showed the worst performance in this variable $-0.43(95 \% \mathrm{CI}:-0.56$ to -0.30 ; $\mathrm{N}$ : $4,628)$. In the analysis of the studies which had a control group, it was observed that there was no statistically significant difference between groups $-0.30(95 \% \mathrm{CI}:-0.63 \text { to } 0.03 \text {; N: } 147)^{(1,3,31)}$. However, in the meta-analysis of the studies altogether, working memory was worse in transplanted patients $-0.42(95 \% \mathrm{CI}:-0.54$ to -0.29 ; N: 4,775) (FIGURE 3.D).

\section{Processing speed - PSI}

Seven studies evaluated this variable with WISC (9,12,16-19,31). The meta-analysis showed worse cognitive processing speed -3.00 (95\% CI: -4.67 to -1.33 ; N: 5,355$)$ in the five studies compared with reference values ${ }^{(9,12,17-19)}(20,11,21,14,22)$. Decline in this variable was also found in the meta-analysis of the studies which had a control group -7.20 (95\% CI: -12.12 to $-2.28 ; \mathrm{N}$ : 147$)^{(16,31)}$, as well as in the general analysis $-3.43(95 \% \mathrm{CI}$ : -5.02 to -1.85 ; N: 5,128$)$ the PSI in the 5 to 18 year old sample (FIGURE 3.E).

\section{Expressive and receptive language}

Two studies evaluated expressive and receptive language in children aged 2 to 12 years. (FIGURE 3.F,G) ${ }^{(4,29)}$. The metaanalysis demonstrated that there was no statistically significant difference between groups in terms of expressive language -0.78
(95\%CI: -1.99 to $0.42 ; \mathrm{N}$ : 921 ). In turn, the meta-analysis showed lower performance in receptive language among transplanted children $-0.85(95 \% \mathrm{CI}$ : -1.16 to $-0.53 ; \mathrm{N}$ : 921$)$ in relation to the contrasted groups.

\section{Motor skill}

Four studies in this review evaluated general motor skills ${ }^{(15,23,26,27)}$, although using different instruments. In 1989, Stewart et al. ${ }^{(15)}$ evaluated motor skills before and after LT. They observed that there was an improvement in the scores after the surgical intervention (74.4 $\pm 22.4 ; 75.4 \pm 21.4)$, although they still remained below expectations (values below 80 of the MCDI) in children with an average age of 4 years. In the 4 year prospective follow-up that Van Mourik et al. conducted in their population aged 12 months to 5 years, it was identified that this variable was not reduced in the pre-transplant sample (90.6 \pm 4.6$)$; however, the scores only improved 1 and 4 years after LT $(93.8 \pm 2.8 ; 97.3 \pm 4.4 \text {, respectively })^{(27)}$.

Wayman et al. ${ }^{(26)}$ also carried out a prospective study and evaluated children under 2 years of age in three moments: before, 3 and 12 months after LT. They found scores with a standard deviation $(82.5 \pm 13)$ below the Bayley's normal values $(100 \pm 15)$ in the moment pre-LT, which were reduced by two standard deviations $(69 \pm 16.1)$ 3 months after the surgical procedure and were reestablished to pre-LT values 1 year later $(80.9 \pm 8.7)$. Almas et al. found in a 4 year follow-up of a longitudinal cohort an impaired general motor function (8.12 \pm 1.88$)$ compared to the control group $(3.5 \pm 1.46)$. The $\mathrm{M}-\mathrm{ABC}$ made it possible to assess other motor aspects that were affected, such as manual dexterity (3.5 \pm 1.74$)$, when compared to the control group (1.24 \pm 0.9$)$, and skill with the ball $(1.75 \pm 1.18)$ and balance $(1.62 \pm 1.3)$ when compared to healthy controls $(0.6 \pm 0.6$ and $0.47 \pm 0.6$, respectively) ${ }^{(23)}$.

\section{NEUROPSYCHOMOTOR RESULTS OF CHILDREN AND ADOLESCENTS WITH NATIVE LIVER}

\section{Neurocognitive results (FSIQ, VIQ, WMI)}

Stewart et al. in $1988^{(21)}$ analyzed the verbal and total coefficients of children with clinical manifestations in the first year of life $(2 \pm 3$ months) and after that period ( $7 \pm 3.5$ years) and identified that children with early symptoms had full and verbal IQ scores ( $85 \pm 8.8$; $86.3 \pm 10.6$ respectively) lower than those of children with late manifestations liver disease (99.5 $\pm 13.8 ; 96.2 \pm 9.2)$ (FIGURE 4.A).

The meta-analysis demonstrated a lower FSIQ when compared to the control group -2.28 (95\% CI: -4.26 to $-0.29 ; \mathrm{N}$ : 94$)$ in two studies in children with preservation of their native livers aged between 2 months and 18 years ${ }^{(11,21)}$.

Working memory $(54 \pm 11)$ and other cognitive variables were not compromised in children with an average age of $11 \pm 3$ years infected with hepatitis $C$ virus in the initial stage of the disease in the study by Rodrigue et al., when compared with normal values $(50 \pm 10)^{(33)}$.

\section{EXPRESSIVE AND RECEPTIVE LANGUAGE}

Two studies checked the expressive and receptive language (FIGURE 4.B,C) using the MSEL instrument ${ }^{(10,24)}$ in babies aged 3 to 21 months. The expressive language in the meta-analysis proved to be reduced compared to reference values -40.32 (95\% CI: -79.74 to -0.89 ; $\mathrm{N}: 3,746$ ) while receptive language scores. Receptive language did not show statistically significant differences between groups -31.85 (95\%CI: -75.38 to 11.67 ; $\mathrm{N}: 3,746)$. 


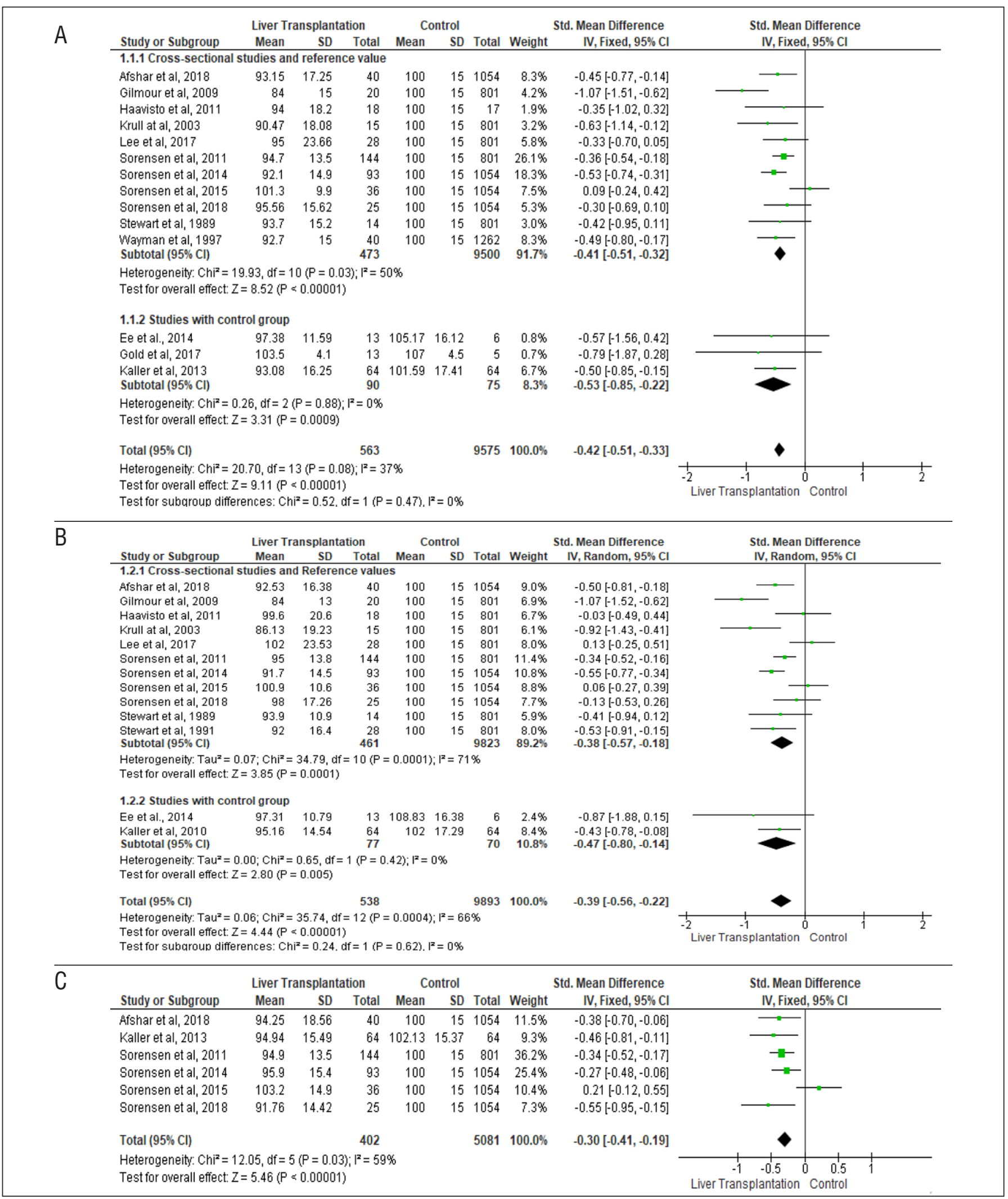

FIGURE 3. Meta-analysis comparing developmental aspects of children and adolescents after liver transplantation in the group control. A. FSIQ - full scale intelligence quotient. B. VIQ -verbal intelligence quotient. C. PRI - Perceptual Reasoning Index. 


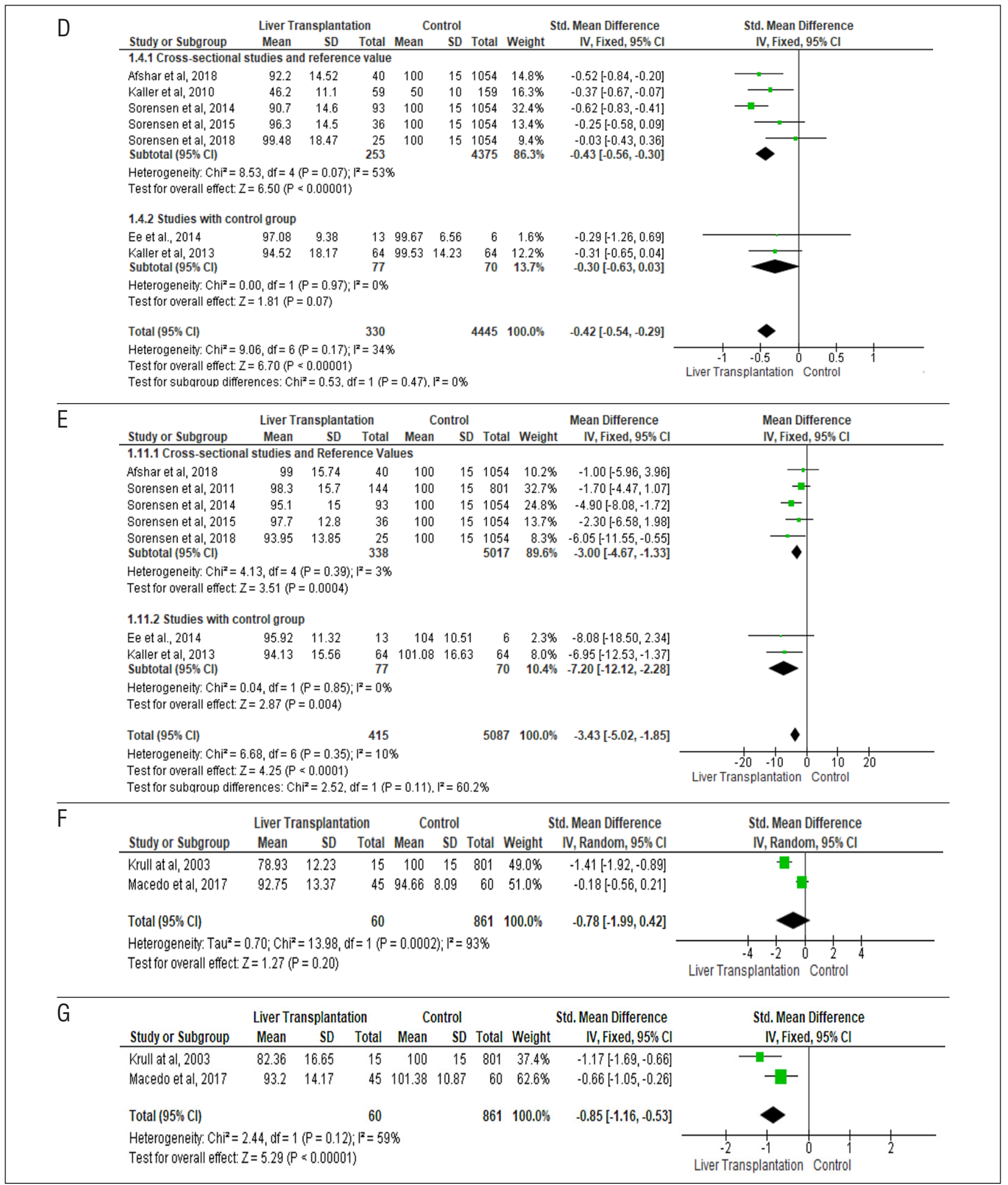

FIGURE 3. Meta-analysis comparing developmental aspects of children and adolescents after liver transplantation in the group control. D. WMI, Working Memory Index. E. PSI - Processing Speed Index. F. Expressive language and (G). G. Receptive language. 


\section{Manual dexterity}

Two studies evaluated manual dexterity with MSEL ${ }^{(10,24)}$. The meta-analysis showed that there were no differences between the group with liver disease and the group with reference values -28.18 (95\%CI: -72.20 to 15.84 ; N: 3,746) (FIGURE 4.D).

\section{Ability with a ball}

Two studies assessed ball skills with MSEL ${ }^{(10,24)}$. The metaanalysis showed that this ability was reduced in children with liver disease $-46.29(95 \% \mathrm{CI}$ : -81.55 to $-11.03 ; \mathrm{N}: 3,746)$ compared to the groups with reference values (FIGURE 4.E).

$\mathrm{NG}$ et al. identified that 1-year-old children with BA presented a higher risk of delayed neurocognitive development even after hepatoportoenterostomy surgery. General motor $(89.0 \pm 13.6)$ and language (92.5 \pm 14.4$)$ skills presented low performance when compared with Bayley's normal values $(100 \pm 15)^{(25)}$.

\section{DISCUSSION}

In this systematic review, the meta-analysis indicates that children and adolescents with acute and/or chronic liver diseases have a deficit in neuropsychomotor development. With LT, these results improve, but many of them do not reach the neurodevelopment of healthy children. Those with their native livers also show low neurocognitive results. Children with hepatic manifestations in the first 2 years of life have lower neurodevelopmental scores because they are exposed to pathogenicity in the period of rapid development and maturation of the neural system, and because they remain with the liver disease longer.

Although LT improves patient survival, cognitive scores remain low and may compromise school performance and the future independence of these children and adolescents. Sorensen et al. reported in their multicenter study that children who received a

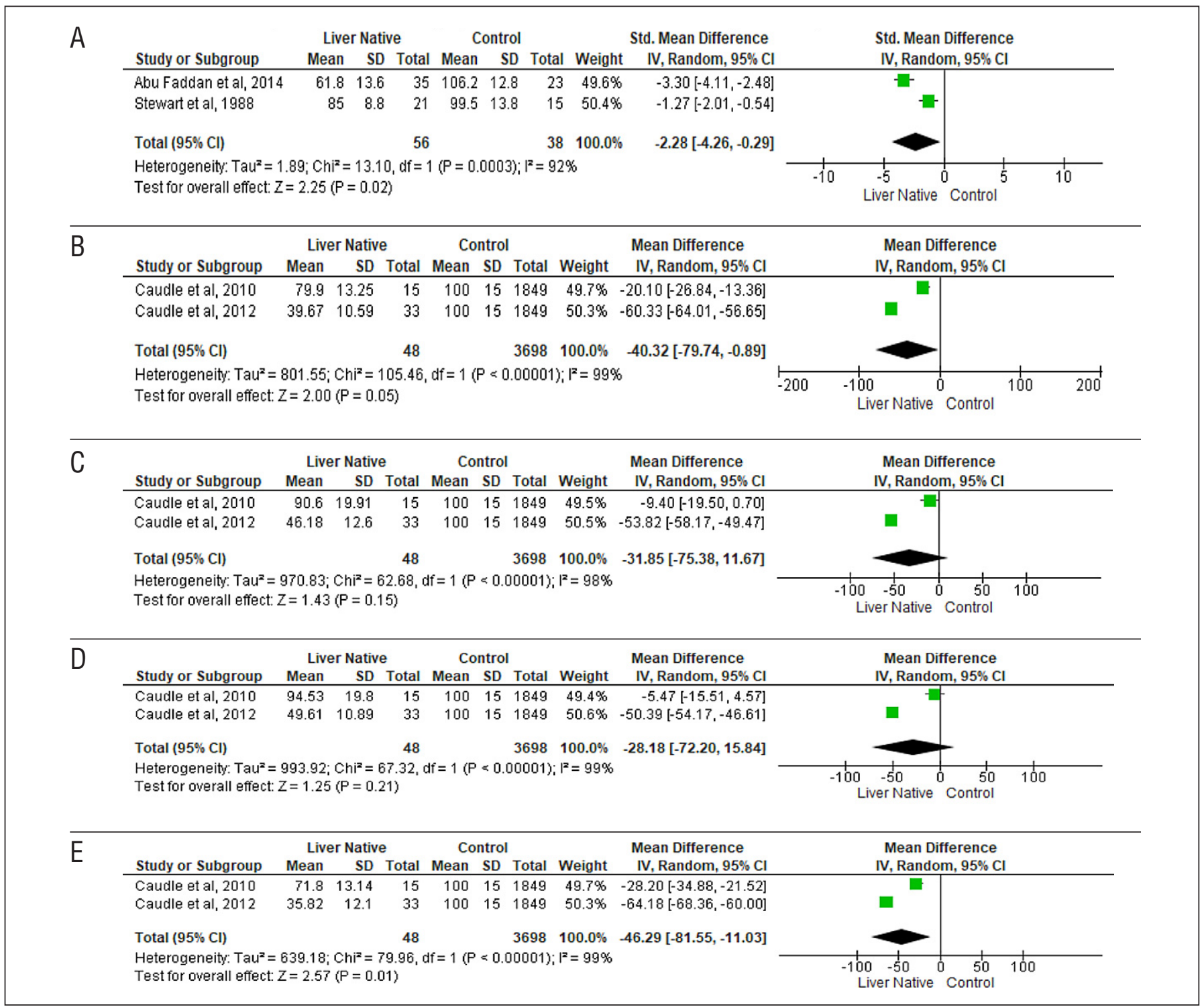

FIGURE 4. Meta-analysis comparing developmental aspects of children and adolescents liver native in the group control. A. FSIQ - full scale intelligence quotient. B. Expressive language. C. Receptive language. D. Fine motor. E. Gross motor. 
liver transplant before the age of 5 years had twice the rate of intellectual delay and thrice the rate of learning difficulties compared to the general population ${ }^{(27,34)}$. The vulnerability of the nervous system in advanced liver disease in the first months of life worsens intellectual development, as this is the time of greatest neurological development. Associated with this, the waiting time to perform the transplantation procedure can enhance the deficits, especially in those children with chronic liver diseases when compared with those with acute liver diseases ${ }^{(28,31)}$.

Neurotoxic aspects are important in the context of advanced liver disease and cirrhosis. Ammonia is the neurotoxin that best characterizes the pathogenesis of chronic encephalopathy in these patients. Residues of this substance accumulate in the systemic circulation, as the liver is unable to eliminate it. Such toxins cross the blood-brain barrier, and excess ammonia is able to cause changes in astrocytes and consequently generate hepatic encephalopathy ${ }^{(35)}$.

In 2009, Gilmour et al. ${ }^{(28)}$ identified an elevation of pre-LT serum ammonia and proved its correlation with low cognitive performance. The most relevant neurotoxicity in their study was due to elevation of calcineurin inhibitors, an immunosuppressant used after LT. They observed a worse performance in total and verbal IQ, since this medication can cause cumulative injuries and consequent neurological deterioration. (The authors Gilmour et al. justify their results of worse deficits when using this medication).

The general analysis of the studies showed that working memory was impaired in children and adolescents with liver diseases. Working memory is a system of limited capacity that allows temporary reservation and manipulation of information to perform complex skills such as language, learning and reasoning ${ }^{(36,37)}$. It is believed that the use of corticosteroids after LT can be toxic to the hippocampus, an essential area for learning and memory ${ }^{(34)}$. The study by Ee LC et al. evaluated children in a long-term approach post-LT (10 years post-LT), thus allowing a greater time for recovery in this score in relation to short-term studies ${ }^{(16)}$. They also used a sibling control group, preventing that the effect of genetic and family environment compromised the results. Kaller et al. argued that their cognitive scores were not significantly different from the average of the population without liver disease ${ }^{(17,32)}$. As the LT of their sample were performed in children younger than 12 months, that is, at an early moment, these children were less exposed to the disease, contradicting the literature, which shows that children affected in early childhood with liver diseases and submitted to LT have greater risk for cognitive delays ${ }^{(38)}$. Naturally, multiple factors contribute to full development and all cognitive and motor skills, the types of stimuli that these children receive, and the chronic diseases themselves can compromise this development.

Children performed worse in receptive language, the maturational course of language development occurs in an orderly manner, where the regions related to receptive language are myelinated earlier than those responsible for functions of expressive language ${ }^{(39)}$. This was perhaps a justification, because the study by de-Paula et al. ${ }^{(4)}$, whose population had an average age of 17 months, influenced the result of the meta-analysis.

The meta-analysis of the group of children who remained with their native livers obtained opposite results to the group post-LT, that is, the expressive language was reduced, while receptive language showed no statistical differences. Nonspecific factors can influence language acquisition in children with liver disease, including social deprivation, malnutrition, family income and educational level of parents, in addition to methodological aspects of the studies included (reduced sample, different assessment instruments) $)^{(5,15,18,28)}$. It was clear that children with native livers had language deficit when compared to children post-LT, and even transplanted children did not achieve scores equal to those of healthy children without liver disease.

This review demonstrated that the motor capacity of children with liver disease was impaired. The time of exposure to the disease and its severity are crucial to the increase in neuromotor and cognitive deficits ${ }^{(6,18,21,25,29)}$. The underlying disease that compromises the multiple functions of the liver, malnutrition (which causes loss of muscle mass and weakness), the presence of ascites, and recurrent hospitalizations clearly diminish the opportunities for the performance of fundamental motor experiments in order to achieve a good development, impairing functional capacity at home and at school ${ }^{(40)}$. When submitted to transplantation, there was an improvement in survival and a reduction in mortality in these patients, but postoperative effects such as rejections, vascular problems, neurotoxicity of the drugs, reduced motor activity, together and in combination, can continue to impair fine and gross motor acquisition and development ${ }^{(15,40)}$. It is, therefore, suggested that surgical approaches to mitigate the effects of liver disease should be performed early, and children who cannot undergo immediate surgical treatment and also those who receive a conservative therapeutic approach require support from a multidisciplinary team to minimize the deleterious effects on neurodevelopment.

This study had as limitations the fact that the inserted articles presented heterogeneous liver diseases, time of follow-up in the cohorts (short- and long-term), assessment instruments, and age variation of children and adolescents.

In view of these outcomes and limitations, studies addressing specific liver diseases, particularly those more prevalent in the pediatric population, and with less variability in the age of the population and instruments for assessing neurodevelopment are recommended. Long-term follow-up can be a possibility to broaden the understanding of the academic and work performance of LT survivors. Children who remain with their native livers need to be better investigated at older ages, as there is a lack of studies with adolescents and young people. Knowing how these patients carry on their academic and professional lives after reaching adult age could confirm which therapeutic approaches are the best or which changes in medical care are necessary.

\section{CONCLUSION}

Acute or chronic liver disease can cause declines in cognitive, motor and language functions. Liver transplantation appears as a therapeutic possibility to reduce mortality and improve quality of life. Although the scores improve after LT, children with liver disease remain below average when compared to healthy children without chronic conditions. Early diagnosis and interventions in this population seem to be the path to less exposure to liver disease and less damage to neurodevelopment.

\section{Authors' contribution}

Santos JC, Saquetto MB, Gomes Neto M, Santos JL and Silva LR contributed substantially to the conception or design of the work; or the acquisition, analysis, or interpretation of data for the work. They prepared and critically reviewed the manuscript, as well as approved the final version and are responsible for all aspects of the work. 


\section{Orcid}

Juliana Costa Santos: 0000-0002-4718-2353.

Micheli Bernardone Saquetto: 0000-0003-3211-8102.
Mansueto Gomes Neto: 0000-0002-0717-9694.

Josiane de Lima dos Santos: 0000-0001-7143-0583.

Luciana Rodrigues Silva: 0000-0003-2995-8581.

Santos JC, Saquetto MB, Gomes Neto M, Santos JL, Silva LR. Desenvolvimento neuropsicomotor em crianças e adolescentes com doenças hepáticas: revisão sistemática com meta-análise. Arq Gastroenterol. 2021;58(2):217-26.

RESUMO - Contexto - A natureza da doença hepática, curso evolutivo e duração das hepatopatias, bem como grau de severidade e incapacidade podem desencadear desfechos múltiplos e com repercussões na aquisição e desenvolvimento neuromotores. Objetivo - Revisar sistematicamente e avaliar por meta-análise os efeitos da doença hepática sobre o desenvolvimento neuropsicomotor de crianças e adolescentes com seus fígados nativos e aquelas que realizaram transplante hepático. Métodos - As buscas foram realizadas nas bases de dados PubMed e periódicos Scopus desde as primeiras publicações na década de 1980 até junho de 2019, de estudos observacionais. Um valor de 0,05 foi considerado significativo. A heterogeneidade estatística do efeito do tratamento entre os estudos foi avaliada pelo teste Q de Cochran e o teste de inconsistência I2, no qual valores acima de 25 e $50 \%$ foram considerados indicativos de heterogeneidade moderada e alta, respectivamente. As análises foram realizadas com o Review Manager 5.3. Resultados - Vinte e cinco estudos preencheram os critérios de elegibilidade, incluindo 909 crianças e adolescentes com doenças hepáticas. As meta-análises mostraram déficits QI total -0,41 (IC 95\%: -0,51 até -0,32; N: 9.973), QI verbal -0,38 (IC 95\%; -0,57 até -0,18; N: 10.284) e linguagem receptiva -0,85 IC 95\%: -1,16 até -0,53; N: 921) nos transplantes hepáticos e as com fígados nativos que apresentaram sintomas precocemente tinham escores de QI total e verbal $(85 \pm 8,8 ; 86,3 \pm 10,6$ respectivamente) menores do que aquelas com manifestações tardias $(99,5 \pm 13,8 ; 96,2 \pm 9,2)$. Habilidade motora grossa apresentou-se reduzida -46,29 (IC 95\%: -81,55 até -11,03; N: 3.746). Conclusão - A doença hepática aguda ou crônica pode determinar declínios nas funções cognitivas, motoras e de linguagem. Muito embora, os escores melhorem após transplante hepático, as crianças continuam abaixo da média quando comparadas às crianças sadias.

Palavras-chave - Doença hepática; transplante de fígado; desenvolvimento infantil.

\section{REFERENCES}

1. Santos ER, Fagundes EDT, Ferreira AR, Queiroz TCN, Hosken CC. Autoimmune liver disease in children and adolescents. Rev Médica Minas Gerais. 2017;27(Supl 3):44-50.

2. Dimensionamento dos Transplantes no Brasil e em cada Estado (2011-2018). Associação Brasileira de Transplante de Órgãos. 2018. [Internet]. Available from: http://www.abto.org.br/abtov03/upload/file/rbt/2018/lv_rbt-2018.pdf

3. Brasil. Ministério da Saúde. Secretaria de Atenção à Saúde. Protocolo Clínico e Diretrizes Terapêuticas para imunossupressão no transplante hepático em Pediatria. 2013;1-19.

4. De-Paula EM, Porta G, Tannuri ACA, Tannuri U, Befi-Lopes DM. Language assessment of children with severe liver disease in a public service in Brazil. Clinics. 2017;72:351-7.

5. Lee JM, Jung YK, Bae JH, Yoon SA, Kim JH, Choi YR, et al. Delayed transplantation may affect intellectual ability in children. Pediatr Int. 2017;59:1080-6.

6. Rodijk LH, Den Heijer AE, Hulscher JBF, Verkade HJ, De Kleine RHJ, Bruggink JLM. Neurodevelopmental outcomes in children with liver diseases: A systematic review. J Pediatr Gastroenterol Nutr. 2018;67:157-68.

7. Wells GA, Shea B, O'Connell D, Peterson J, Welch V, Losos M, Tugwell P. The Newcastle-Ottawa Scale (NOS) for Assessing the Quality of Non-Randomized Studies in Meta-Analysis. Ottawa Hosp Res Inst. 2011.

8. Figueiredo VLM, Pinheiro S. WISC-III test adaptation with Rio Grande do Sul sample Temas em Psicol. [Internet]. [cited 2021 April 21]. 1998;6:25561. Available from: http://pepsic.bvsalud.org/scielo.php?script=sci_arttext\&pid=S1413-389X1998000300008\&lng=pt.

9. Sorensen LG, Neighbors K, Martz K, Zelko F, Bucuvalas JC, Alonso EM. Cognitive and Academic Outcomes after Pediatric Liver Transplantation: Functional Outcomes Group (FOG) Results. Am J Transpl. 2011;11:303-11.

10. Caudle SE, Katzenstein JM, Karpen S, McLin V. Developmental assessment of infants with biliary atresia: Differences between boys and girls. J Pediatr Gastroenterol Nutr. 2012;55:384-9.

11. Abu Faddan NH, Shehata GA, Abd Elhafeez HA, Mohamed AO, Hassan HS, Abd El Sameea F. Cognitive function and endogenous cytokine levels in children with chronic hepatitis C. J Viral Hepat. 2014;22:665-70.

12. Sorensen LG, Neighbors K, Zhang S, Christine A, Varni JW, Ng VL, et al. Neuropsychological Functioning and Health-Related Quality of Life: Pediatric Acute Liver Failure Study Group Results. 2015;60:75-83.

13. Higgins JPT, Thompson SG, Deeks JJ, Altman DG. Measuring inconsistency in meta-analyses. BMJ. 2003;327-557
14. Gold A, Rogers A, Cruchley E, Rankin S, Parmar A, Kamath BM, et al. Assessment of School Readiness in Chronic Cholestatic Liver Disease: A Pilot Study Examining Children with and without Liver Transplantation. Can J Gastroenterol Hepatol. 2017;2017:9873945.

15. Stewart SM, Uauy R, Waller DA, Kennard BD, Benser M, Andrews WS. Mental and motor development, social competence, and growth one year after successful pediatric liver transplantation. J Pediatr. 1989;114:574-81.

16. Ee LC, Lloyd O, Beale K, Fawcett J, Cleghorn GJ. Academic potential and cognitive functioning of long-term survivors after childhood liver transplantation. Pediatr Transplant. 2014;18:272-9.

17. Afshar S, Porter M, Barton B, Stormon M. Intellectual and academic outcomes after pediatric liver transplantation: Relationship with transplant-related factors. Am J Transplant. 2018;18:2229-37.

18. Sorensen LG, Neighbors K, Martz K, Zelko F, Bucuvalas JC, Alonso EM. Longitudinal Study of Cognitive and Academic outcomes after pediatric liver transplantatios. J Pediatr. 2014;165:65-72.

19. Sorensen LG, Neighbors K, Hardison RM, Loomes KM, Varni JW, Ng VL. Health Related Quality of Life and Neurocognitive Outcomes in the First Year after Pediatric Acute Liver Failure. J Pediatr. 2018;196:129-38.

20. Krull KR, Fuchs C, Yurk H, Boone P, Alonso E. Neurocognitive outcome in pediatric liver transplant recipients. Pediatr Transplant. 2003;7:111-8.

21. Stewart SM, Uauy R, Kennard BD, Waller DA, Benser M, Andrews WS. Mental development and growth in children with chronic liver disease of early and late onset. Pediatrics. 1988;82:167-72.

22. Stewart SM, Hiltebeitel C, Nice J, Uauy R, Waller DA, Uauy R. Neuropsychological outcomes of pediatric liver transplnatation. Pediatrics. 1991;87:367-76.

23. Almaas R, Jensen U, Loennecken MC, Tveter AT, Sanengen T, Scholz T, et al. Impaired motor competence in children with transplanted liver. J Pediatr Gastroenterol Nutr. 2015;60:723-8.

24. Caudle SE, Katzenstein JM, Karpen SJ, McLin VA. Language and Motor Skills Are Impaired in Infants with Biliary Atresia Before Transplantation. J Pediatr. 2010;156:936-40.

25. Ng VL, Sorensen LG, Alonso EM, Fredericks EM, Ye W, Moore J, et al. Neurodevelopmental Outcome of Young Children with Biliary Atresia and Native Liver: Results from the ChiLDReN Study. J Pediatr. 2018;196:139-147.e3.

26. Wayman KI, Cox KL, Esquivel CO. Neurodevelopmental outcome of young children with extrahepatic biliary atresia 1 year after liver transplantation. J Pediatr. 1997;131:894-8. 
27. Van Mourik IDM, Beath S V., Brook GA, Cash AJ, Mayer AD, Buckels JAC, et al. Long-term nutritional and neurodevelopmental outcome of liver transplantation in infants aged less than 12 months. J Pediatr Gastroenterol Nutr. 2000; 30:269-75.

28. Gilmour S, Adkins R, Liddell GA, Jhangri G, Robertson CM. Assessment of psychoeducational outcomes after pediatric liver transplant. Am J Transplant. 2009;9:294-300

29. Krull KR, Fuchs C, Yurk H, Boone P, Alonso E. Neurocognitive outcome in pediatric liver transplant recipients. Pediatr Transplant. 2003;7:111-8.

30. Haavisto A, Korkman M, Tormanen J, Holmberg C, Jalanko H, Qvist E. Visuospatial impairment in children and adolescents after liver transplantations. Visuospatial impairment in children and adolescents after liver transplantation. Pediatr Transplant. 2011;15:184-92.

31. Kaller T, Langguth N, Petermann F, Ganschow R, Nashan B, Schulz KH. Cognitive performance in pediatric liver transplant recipients. Am J Transplant. 2013;13:2956-65

32. Kaller T, Langguth N, Ganschow R, Nashan B, Schulz KH. Attention and executive functioning deficits in liver-transplanted childre. Transplantation. 2010;90:1567-73.
33. Rodrigue JR, Balistreri W, Haber B, Jonas MM, Mohan P, Molleston JP, et al. Impact of Hepatitis C Virus Infection on Children and their Caregivers: Quality of Life, Cognitive, and Emotional Outcomes. J Pediatr Gastroenterol Nutr. 2010;48:341-7.

34. Conrad CD. Chronic Stress-induced Hippocampal Vulnerability: The Glucocorticoid Vulnerability Hypothesis. Rev Neurosci. 2008;19:395-412.

35. Sawhney R, Holland-Fischer P, Rosselli M, Mookerjee RP, Agarwal B, Jalan R. Role of ammonia, inflammation, and cerebral oxygenation in brain dysfunction of acute-on-chronic liver failure patients. Liver Transplant. 2016;22:732-42.

36. Pires MM, Estivalet GL. Working memory: a proposal for child evaluating. 2014:39:46-57. Doi: 10.17058/signo.v39i67.5017

37. Alloway TP, Gathercole SE, Adams AM, Willis C. Working memory abilities in children with special educational needs. Educ Child Psychol. 2005;22:56-67.

38. Alonso EM SL. Cognitive development following pediatric solid organ transplantation. Curr Opin Organ Transpl. 2009;14:522-5.

39. Muszkat M, Mello CB. Neurodesenvolvimento e linguagem. In: Neuropsicologia do desenvolvimento: conceitos e abordagens. LTDA MEC, editor. 2006. p. 248.

40. Desmet VJ, Gerber M, Hoofnagle JH, Manns M, Scheuer PJ. Classification of chronic hepatitis: Diagnosis, grading and staging. Hepatology. 1994;19:1513-20. 